\title{
Phytoprotection
}

\section{The role of antibiosis in the antagonism of different bacteria towards Helminthosporium solani, the causal agent of potato silver scurf}

\section{Le rôle de l'antibiose dans l'antagonisme de différentes bactéries contre Helminthosporium solani, agent responsable de la gale argentée de la pomme de terre}

\author{
Carole Martinez, Tyler J. Avis, Jean-Nicolas Simard, Jessica Labonté, Richard R. \\ Bélanger et Russell J. Tweddell
}

Volume 87, numéro 2, août 2006

URI : https://id.erudit.org/iderudit/013975ar

DOI : https://doi.org/10.7202/013975ar

Aller au sommaire du numéro

Éditeur(s)

Société de protection des plantes du Québec (SPPQ)

ISSN

0031-9511 (imprimé)

1710-1603 (numérique)

Découvrir la revue

Citer cet article

Martinez, C., Avis, T. J., Simard, J.-N., Labonté, J., Bélanger, R. R. \& Tweddell, R. J. (2006). The role of antibiosis in the antagonism of different bacteria towards Helminthosporium solani, the causal agent of potato silver scurf / Le rôle de l'antibiose dans l'antagonisme de différentes bactéries contre Helminthosporium solani, agent responsable de la gale argentée de la pomme de terre. Phytoprotection, 87(2), 69-75. https://doi.org/10.7202/013975ar
Résumé de l'article

Des antagonistes bactériens envers Helminthosporium solani ont été soumis à différents essais en vue de déterminer le rôle de l'antibiose dans l'antagonisme observé. Parmi les souches bactériennes évaluées, sept (Alcaligenes piechaudii, Aquaspirillum autotrophicum, Cellulomonas fimi, Pseudomonas chlororaphis, Pseudomonas putida (souches 94-19 et E-30) et Streptomyces griseus) ont produit dans le milieu gélosé des métabolites inhibant la croissance mycélienne et/ou la germination des conidies de $H$. solani. Les métabolites produits en culture pure et en culture mixte ont présenté une activité différente sur la croissance mycélienne de $H$. solani. Les résultats présentés indiquent que la méthodologie employée peut être un facteur déterminant dans l'identification de l'antibiose comme mode d'action d'un agent antagoniste.
Tous droits réservés @ La société de protection des plantes du Québec, 2006
Ce document est protégé par la loi sur le droit d'auteur. L'utilisation des services d'Érudit (y compris la reproduction) est assujettie à sa politique d'utilisation que vous pouvez consulter en ligne.

https://apropos.erudit.org/fr/usagers/politique-dutilisation/ 


\title{
The role of antibiosis in the antagonism of different bacteria towards Helminthosporium solani, the causal agent of potato silver scurf
}

\author{
Carole Martinez ${ }^{1}$, Tyler J. Avis², Jean-Nicolas Simard², Jessica Labonté2, \\ Richard R. Bélanger', and Russell J. Tweddell ${ }^{2}$
}

Received 2006-04-13; accepted 2006-06-22

PHYTOPROTECTION 87 : 69-76

Bacterial antagonists of Helminthosporium solani were submitted to different tests in order to determine the role of antibiosis in their antagonistic interaction. Among the bacterial strains tested, seven (Alcaligenes piechaudii, Aquaspirillum autotrophicum, Cellulomonas fimi, Pseudomonas chlororaphis, Pseudomonas putida (strains 94-19 and E-30) and Streptomyces griseus) were shown to produce agar diffusible metabolites inhibiting $H$. solani mycelial growth and/or conidial germination. Differential activity was revealed when diffusible metabolites were extracted from either pure cultures of these antagonists or dual culture in the presence of $H$. solani. The results presented indicate that the methodology employed could be a decisive factor in whether or not antibiosis can be identified as a mode of action of biocontrol agents.

Keywords: Antibiosis, bacterial antagonists, diffusible metabolites, Helminthosporium solani, potato silver scurf.

[Le rôle de l'antibiose dans l'antagonisme de différentes bactéries contre Helminthosporium solani, agent responsable de la gale argentée de la pomme de terre]

Des antagonistes bactériens envers Helminthosporium solani ont été soumis à différents essais en vue de déterminer le rôle de l'antibiose dans l'antagonisme observé. Parmi les souches bactériennes évaluées, sept (Alcaligenes piechaudii, Aquaspirillum autotrophicum, Cellulomonas fimi, Pseudomonas chlororaphis, Pseudomonas putida (souches 94-19 et E-30) et Streptomyces griseus) ont produit dans le milieu gélosé des métabolites inhibant la croissance mycélienne et/ou la germination des conidies de $H$. solani. Les métabolites produits en culture pure et en culture mixte ont présenté une activité différente sur la croissance mycélienne de $H$. solani. Les résultats présentés indiquent que la méthodologie employée peut être un facteur déterminant dans l'identification de l'antibiose comme mode d'action d'un agent antagoniste.

Mots clés: Antagonistes bactériens, antibiose, Helminthosporium solani, métabolites, gale argentée de la pomme de terre.

\section{INTRODUCTION}

Silver scurf of potato (Solanum tuberosum L.), caused by the fungus Helminthosporium solani Durieu \& Mont., is a surface-blemishing disease spoiling the appearance of potato tubers. Previously recognized as a disease of minor importance, silver scurf has become a leading cause of rejection of commercial potatoes (Errampalli et al. 2001). The dramatic increase in the economic importance of silver scurf is mainly attributable to the development of $H$. solani resistance to thiabendazole, which previously provided efficient control as a post-harvest treatment
(Mérida and Loria 1994; Platt 1997; Secor and Gudmestad 1999). As a result, alternative strategies are needed to control this disease, which is present in most potato-growing areas.

Recent work has shown that various bacteria isolated from potato-growing soils had the ability to reduce H. solani development on potato tubers (Martinez et al. 2002; Michaud et al. 2002). These antagonistic bacteria, which may eventually find application for the biocontrol of $H$. solani, are Alcaligenes piechaudii Kiredjian et al., Aquaspirillum autotrophicum Aragno \& Schlegel, Arthrobacter oxydans Sguros, Bacillus cereus Frankland \& Frankland (GC subgroup A),

1. Centre de recherche en horticulture, Pavillon Envirotron, Université Laval, Québec (Québec), Canada G1K 7P4. Current address: Premier Horticulture, 1 avenue Premier, Rivière-du-Loup (Québec), Canada G5R 6C1

2. Centre de recherche en horticulture, Pavillon Envirotron, Université Laval, Québec (Québec), Canada G1K 7P4; corresponding author e-mail: russell.tweddell@crh.ulaval.ca 
Bacillus mycoides Flügge, Cellulomonas fimi (McBeth \& Scales) Bergey et al., Kocuria rosea (Flügge) Stackebrandt et al., Kocuria varians (Migula) Stackebrandt et al., Pseudomonas chlororaphis (Guignard \& Sauvageau) Bergey et al., Pseudomonas fluorescens Migula biotype F, Pseudomonas putida (Trevisan) Migula biotype A (strains 94-19 and E-30), Rhodococcus erythropolis (Gray \& Thornton) Goodfellow \& Alderson, Rhodococcus globerulus Goodfellow et al. (GC subgroup A), and Streptomyces griseus (Krainsky) Waksman \& Henrici.

Considering the potentially effective antagonism of these micro-organisms against $H$. solani, the determination of their mode of action is of great importance both on scientific grounds and in view of possibly developing one or more of these bacteria as biocontrol agents in the future. There are four mechanisms by which one micro-organism may limit the growth of another micro-organism: competition for resources, parasitism, systemic induced resistance and antibiosis (i.e. the production and diffusion of toxic compounds (antibiotics); Fravel 1988). Although these mechanisms often work in concert, antibiosis is of great importance in many antagonists as it usually provides the initial mechanism (Bélanger et al. 1995), as well as the most rapid means (Avis et al. 2000), of limiting the growth of a plant pathogen.

As such, this work attempted to determine the role of antibiosis in the mechanism by which the identified antagonistic bacteria affect $H$. solani development. The objectives of this study were (i) to determine the effect of bacterial strains on mycelial growth of $H$. solani in dual culture on solid media; and (ii) to evaluate the antifungal activity of crude and semipurified bacterial extracts on mycelial growth and conidial germination of $H$. solani.

\section{MATERIALS AND METHODS}

\section{Micro-organisms and growth conditions}

Helminthosporium solani (DAOM 233452) was used throughout this study. The fungus was grown $\left(24^{\circ} \mathrm{C}\right)$ on V8 agar containing $200 \mathrm{~mL} \mathrm{~L}^{-1}$ of clarified V8 juice (Campbell's Soup Company, Toronto, Ontario), $3 \mathrm{~g} \mathrm{~L}^{-1}$ of $\mathrm{CaCO}_{3}$ and $15 \mathrm{~g} \mathrm{~L}^{-1}$ of bacto agar (Difco Laboratories, Becton Dickinson, Sparks, MD). The $\mathrm{pH}$ was adjusted to 7.2. Stock cultures were maintained on slants at $4^{\circ} \mathrm{C}$.

The bacterial antagonists tested were previously isolated from soil (Martinez et al. 2002; Michaud et al. 2002). These micro-organisms were: $A$. piechaudii, $A$. autotrophicum, $A$. oxydans, $B$. cereus (GC subgroup A), B. mycoides, C. fimi, K. rosea, $K$. varians, $P$. chlororaphis, $P$. fluorescens, $P$. putida biotype A (strains 94-19 and E-30), $R$. erythropolis, $R$. globerulus (GC subgroup A) and S. griseus. All strains were grown in tryptic soy broth (TSB; Sigma-Aldrich, Mississauga, ON) for $24 \mathrm{~h}$ on a rotary shaker at $24^{\circ} \mathrm{C}$, with the exception of $S$. griseus, which was grown for $4 \mathrm{~d}$ under the same conditions.

\section{Effect of bacteria on mycelial growth of $H$. solani}

A mycelial disk (8 $\mathrm{mm}$ diam) of a 5-wk-old culture of $H$. solani was placed on one side of a Petri dish containing potato dextrose agar (PDA; Difco Laboratories). Ten microlitres of each bacterial sus-

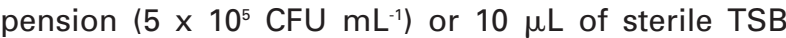
(control) was placed $1 \mathrm{~cm}$ away from the $H$. solani disk, and dishes were incubated at $24^{\circ} \mathrm{C}$ in the dark. The presence of inhibition zones was recorded $14 \mathrm{~d}$ after inoculation. The experiment was performed in triplicate.

\section{Effect of bacterial exudates released on solid media on $\boldsymbol{H}$. solani mycelial growth}

Preparation of extracts obtained from pure bacterial cultures

Cellophane membranes (Hutchinson, Chalettes/Loing, France) were boiled in distilled water for $5 \mathrm{~min}$ and sterilized (Whipps 1987). Selected bacteria were streaked on sterile cellophane membranes covering agar plates containing $24 \mathrm{~g} \mathrm{~L}^{-1}$ potato dextrose broth (PDB; Difco Laboratories) and $17 \mathrm{~g} \mathrm{~L}^{-1}$ Phytagel (Sigma-Aldrich), and grown at $24^{\circ} \mathrm{C}$ for $3 \mathrm{~d}$. The cellophane membranes were then removed and the media were lyophilized. Agar plates covered by a cellophane membrane on which TSB alone was streaked were used as controls.

Preparation of extracts obtained from bacteria in dual culture with $\mathrm{H}$. solani

A mycelial disk ( $8 \mathrm{~mm}$ diam) of a 5 -wk-old culture of $H$. solani was placed on one side of a Petri dish containing PDB-Phytagel, prepared as described previously. Ten microlitres of each bacterial suspension

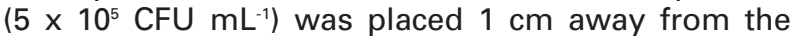
$H$. solani disk and dishes were incubated at $24^{\circ} \mathrm{C}$ in the dark. When inhibition zones appeared, the medium between the bacteria and $H$. solani was recovered and lyophilized. An equivalent zone of the medium on which $H$. solani had grown in the presence of $10 \mu \mathrm{L}$ TSB was used as the control.

Effect of the extracts on mycelial growth

Lyophilized media samples were ground and extracted with $50 \mathrm{~mL}$ of $80 \%$ methanol for $1 \mathrm{~h}$. Evaporation of methanol was performed with a roto-evaporator (Rotovapor R-114, Büchi, Switzerland) and the volume was reduced to $2 \mathrm{~mL}$. Ten millilitres of water were added and the samples were eluted with reversephase C-18 columns (Sep-pak Cartridges, Waters Corporation, Milford, MA), previously washed with methanol and conditioned with water. Elutions were performed with a methanol:water gradient $(0,20,50$, 80 and $100 \%$ of methanol identified F1 through F5, respectively). Six millilitres of each of the five fractions were evaporated to dryness with a roto-evaporator. After evaporation, fractions F1 and F2 were dissolved in $1 \mathrm{~mL}$ of methanol:water (1:1), and fractions F3, F4 and $\mathrm{F} 5$ were dissolved in $1 \mathrm{~mL}$ of $100 \%$ methanol. The fractions were stored at $-20^{\circ} \mathrm{C}$ until use. To evaluate the effect of the fractions on $H$. solani mycelial growth, $100 \mu \mathrm{L}$ of each fraction were absorbed on a disk of paper filter ( $4 \mathrm{~mm}$ diam). Each disk was placed $5 \mathrm{~mm}$ away from a 7-d-old culture of $H$. solani. Presence (+) or absence (-) of an inhibition zone was recorded after a 6 -d incubation period at $24^{\circ} \mathrm{C}$ in the dark. Each 
bioassay was performed in triplicate. Fractions were considered inhibitory when an inhibition zone appeared in at least two repetitions.

\section{Effect of bacterial exudates on conidial germination of $\boldsymbol{H}$. solani}

\section{Effect of liquid culture filtrates}

Bacteria were grown in Erlenmeyer flasks (100 mL) containing $50 \mathrm{~mL}$ of TSB for $24 \mathrm{~h}$ at $24^{\circ} \mathrm{C}$ on a rotary shaker (150 rpm). The culture filtrates were recovered by centrifugation (10 min; $4800 \times g$ ) and sterilized with a syringe filter $(0.2 \mu \mathrm{M})$. Helminthosporium solani conidia $\left(5 \times 10^{4}\right)$ in $1 \mathrm{~mL}$ of each culture filtrate or sterile TSB (control) were placed in a $1.5 \mathrm{~mL}$ microtube. Microtubes were incubated at $24^{\circ} \mathrm{C}$ in the dark under agitation (rotary shaker; $150 \mathrm{rpm}$ ), and conidial germination was noted after a $24-\mathrm{h}$ incubation period (fungistatic effect). In order to evaluate the fungitoxic effect of the filtrates, conidia were recovered by centrifugation (3200 rpm; $5 \mathrm{~min}$ ), rinsed three times with TSB and incubated for an additional $48 \mathrm{~h}$ in TSB on a rotary shaker $\left(150 \mathrm{rpm} ; 24^{\circ} \mathrm{C}\right)$ in the dark prior to measuring conidial germination. In both assays, the level of germination was evaluated on 100 conidia with a microscope. The conidia were considered germinated when the length of the germ tube was equal to 1.5 times the length of the conidia. Inhibition of conidial germination was calculated as follows: [(Number of germinated conidia in the control Number of germinated conidia in the filtrate)/ Number of germinated conidia in the control] $x 100$. The experimental unit was a microtube containing $1 \mathrm{~mL}$ of $H$. solani conidial suspension and the experiment was performed according to a completely randomized design with three repetitions. Analysis of variance was carried out with the GLM procedure of SAS (SAS Institute, Cary, NC) and treatment means were compared using Fisher's protected LSD test $(P<0.05)$.

Effect of bacterial exudates released on solid media Sterile cellophane membranes were placed on $10 \mathrm{~mL}$ of PDA in Petri dishes. A 24-h-old TSB liquid culture

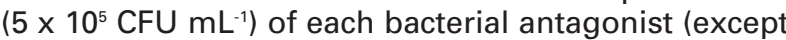
for $S$. griseus) or sterile TSB (control) was streaked on the cellophane membranes. Petri dishes were incubated at $24^{\circ} \mathrm{C}$ for $3 \mathrm{~d}$. For S. griseus, a 4-d-old TSB liquid culture was streaked on the cellophane membranes and incubated at $24^{\circ} \mathrm{C}$ until it sporulated. The cellophane membranes were then removed and $1 \mathrm{~mL}$ of $H$. solani conidial suspension $\left(10^{4}\right.$ conidia $\left.\mathrm{mL}^{-1}\right)$ was spread on PDA. Petri dishes were incubated at $24^{\circ} \mathrm{C}$ for $6 \mathrm{~d}$ and germination was evaluated visually. Each bacterium was tested in triplicate.

\section{RESULTS}

\section{Effect of bacteria on mycelial growth of $\boldsymbol{H}$. solani}

In confrontation assays, an inhibition zone was observed between $H$. solani and the bacteria $A$. piechaudii, $A$. autotrophicum, C. fimi, P. chlororaphis, P. putida (94-19 and E-30) and $S$. griseus (Table 1), revealing that $H$. solani mycelial growth was inhibited by these bacteria.
Table 1. Effect of bacterial antagonists on the mycelial growth of Helminthosporium solani in dual culture

\begin{tabular}{|c|c|}
\hline Bacterial antagonist & Inhibition zone ${ }^{a}$ \\
\hline Sterile TSB ${ }^{\mathrm{b}}$ (control) & -- \\
\hline Alcaligenes piechaudii & +++ \\
\hline Aquaspirillum autotrophicum & +++ \\
\hline Arthrobacter oxydans & -- \\
\hline Bacillus cereus & $-\ldots$ \\
\hline Bacillus mycoides & $-{ }_{-}$ \\
\hline Cellulomonas fimi & +++ \\
\hline Kocuria rosea & -- \\
\hline Kocuria varians & $-\ldots$ \\
\hline Pseudomonas chlororaphis & +++ \\
\hline Pseudomonas fluorescens & -- \\
\hline Pseudomonas putida (94-19) & +++ \\
\hline Pseudomonas putida (E-30) & +++ \\
\hline Rhodococcus erythropolis & -- \\
\hline Rhodococcus globerulus & $-\ldots$ \\
\hline Streptomyces griseus & +++ \\
\hline
\end{tabular}

a Presence (+) or absence (-) of an inhibition zone between the antagonist and $H$. solani for each of three repetitions. b Tryptic Soy Broth.

\section{Effect of bacterial exudates released on solid media on $\boldsymbol{H}$. solani mycelial growth}

Fractions extracted from pure culture of the bacteria that inhibited $H$. solani growth in dual culture $(A$. piechaudii, A. autotrophicum, C. fimi, P. chlororaphis, P. putida (94-19 and E30) and S. griseus) were tested for their effect on mycelial growth of $H$. solani. For all the bacteria tested, at least one fraction exhibited inhibition of $H$. solani mycelial growth (Table 2). Fraction F4 was active in $A$. piechaudii, $\mathrm{F} 3$ in $A$. autotrophicum, F4 in C. fimi, F4 and F5 in P. chlororaphis, F4 in P. putida (94-19), F4 and F5 in P. putida (E-30), and F2 through F4 in S. griseus.

Fractions extracted from the inhibition zone between $H$. solani and each of the seven selected antagonists were also tested for their effect on mycelial growth of $H$. solani (Table 2). At least one fraction inhibited the growth of $H$. solani in $A$. piechaudii, C. fimi, P. chlororaphis, P. putida (94-19) and S. griseus. Aquaspirillum autotrophicum and $P$. putida (E-30) did not contain consistently active fractions. Active fractions in the bacterial antagonists were: F4 and F5 in A. piechaudii, F2 in C. fimi, F4 in P. chlororaphis, F4 in P. putida (94-19), and F2 and F3 in S. griseus.

\section{Effect of bacterial exudates on conidial germination of $\boldsymbol{H}$. solani}

For the fungistatic assay, culture filtrates from $B$. cereus, $K$. rosea and $P$. fluorescens significantly inhibited conidial germination when compared with the control with inhibition rates of $59.7,24.8$, and $73.3 \%$, respectively (Table 3 ). Filtrates from $R$. erythropolis and $R$. globerulus significantly stimulated conidial germination. In the fungitoxic assay, $B$. cereus and $K$. rosea culture filtrates significantly decreased $H$. solani conidial germination with inhibition rate of 40.4 and $45.1 \%$, respectively (Table 3 ), while $A$. piechaudii, $P$. fluorescens and $R$. globerulus filtrates significantly stimulated $H$. solani conidial germination. 
Table 2. Effect of semi-purified extracts from bacteria grown in pure culture and in dual culture on the mycelial growth of Helminthosporium solani

\begin{tabular}{|c|c|c|c|}
\hline Bacterial antagonist & Fraction $^{\mathrm{a}}$ & Pure culture & Dual culture $^{b}$ \\
\hline \multirow[t]{5}{*}{ Control } & 1 & $--^{c}$ & -- \\
\hline & 2 & --- & --- \\
\hline & 3 & -- & -- \\
\hline & 4 & -- & -- \\
\hline & 5 & --- & --- \\
\hline \multirow[t]{5}{*}{ Alcaligenes piechaudii } & 1 & -- & +-- \\
\hline & 2 & -- & -- \\
\hline & 3 & --- & -- \\
\hline & 4 & +++ & +++ \\
\hline & 5 & --- & ++- \\
\hline \multirow[t]{5}{*}{ Aquaspirillum autotrophicum } & 1 & -- & +-- \\
\hline & 2 & --- & --- \\
\hline & 3 & +++ & --- \\
\hline & 4 & - - & -- \\
\hline & 5 & -- & -- \\
\hline \multirow[t]{5}{*}{ Cellulomonas fimi } & 1 & -- & --- \\
\hline & 2 & --- & +++ \\
\hline & 3 & -- & -- \\
\hline & 4 & ++- & -- \\
\hline & 5 & -- & -- \\
\hline \multirow[t]{5}{*}{ Pseudomonas chlororaphis } & 1 & +- & -- \\
\hline & 2 & +-- & -- \\
\hline & 3 & +-- & -- \\
\hline & 4 & ++- & +++ \\
\hline & 5 & +++ & +-- \\
\hline \multirow[t]{5}{*}{ Pseudomonas putida (94-19) } & 1 & -- & --- \\
\hline & 2 & -- & --- \\
\hline & 3 & -- & -- \\
\hline & 4 & +++ & ++- \\
\hline & 5 & - - - & -- \\
\hline \multirow[t]{5}{*}{ Pseudomonas putida (E-30) } & 1 & --- & --- \\
\hline & 2 & -- & +-- \\
\hline & 3 & -- & +- \\
\hline & 4 & ++- & --- \\
\hline & 5 & +++ & --- \\
\hline \multirow[t]{5}{*}{ Streptomyces griseus } & 1 & +-- & --- \\
\hline & 2 & ++- & ++- \\
\hline & 3 & +++ & +++ \\
\hline & 4 & +++ & - - - \\
\hline & 5 & +-- & - - - \\
\hline
\end{tabular}

a Fractions from C-18 cartridges eluted with: $1=100 \%$ water; $2=20 \%$ methanol; $3=50 \%$ methanol; $4=80 \%$ methanol; and $5=100 \%$ methanol.

${ }^{b}$ Extracts recovered from the inhibition zone between the bacterium and $H$. solani.

c Presence (+) or absence (-) of an inhibition zone for each of three replicates.

Conidial germination was also affected by bacterial exudates released on agar. Indeed, precultures of A. piechaudii, $P$. chlororaphis and $S$. griseus on a cellophane membrane covering PDA limited the subsequent germination of $H$. solani conidia either totally ( $P$. chlororaphis) or partially (A. piechaudii and $S$. griseus) (Fig. 1). Precultures of $A$. autotrophicum, C. fimi, P. putida (E-30) and P. putida (94-19) (see Fig. $1 \mathrm{~B}$ as an example of negative control) did not reduce conidial germination of $H$. solani.

\section{DISCUSSION}

This study employed different methodologies to evaluate antibiosis in previously identified bacterial antagonists of $H$. solani. As such, solid or liquid cultures of the antagonists were carried out with or without the presence of the pathogen, and semipurified or crude bacterial culture extracts were tested for inhibition of both mycelial growth and conidial germination of $H$. solani. With this experimental design, antibiosis was assessed with regards to specific conditions governing the differential production of antifungal compounds from selected bacteria. 
Table 3. Effect of culture filtrates from bacterial antagonists on conidial germination of Helminthosporium solani

\begin{tabular}{|c|c|c|}
\hline \multirow[b]{2}{*}{ Bacterial antagonist } & \multicolumn{2}{|c|}{ Inhibition of conidial germination $(\%)^{\mathrm{a}}$} \\
\hline & Fungistatic effect & Fungitoxic effect \\
\hline Control & 0.0 cde & 0.0 cde \\
\hline Alcaligenes piechaudii & -11.6 bcd & -111.2 a \\
\hline Aquaspirillum autotrophicum & -14.1 bc & $-18.4 \mathrm{c}$ \\
\hline Arthrobacter oxydans & -8.0 bcde & -8.0 cde \\
\hline Bacillus cereus & $59.7 \mathrm{~g}$ & $40.4 \mathrm{f}$ \\
\hline Bacillus mycoides & 12.0 ef & $12.0 \mathrm{e}$ \\
\hline Cellulomonas fimi & -2.1 cde & $-13.2 c$ \\
\hline Kocuria rosea & $24.8 \mathrm{f}$ & $45.1 \mathrm{~g}$ \\
\hline Kocuria varians & 10.3 def & 3.9 cde \\
\hline Pseudomonas chlororaphis & $-14.5 \mathrm{bc}$ & -14.5 bc \\
\hline Pseudomonas fluorescens & $73.3 \mathrm{~g}$ & $-57.7 b$ \\
\hline Pseudomonas putida (94-19) & 5.2 cdef & -10.1 cde \\
\hline Pseudomonas putida (E-30) & 11.8 ef & $9.4 \mathrm{de}$ \\
\hline Rhodococcus erythropolis & $-28.1 a b$ & $-14.3 c$ \\
\hline Rhodococcus globerulus & -40.2 a & $-51.7 b$ \\
\hline Streptomyces griseus & $--^{\mathrm{b}}$ & -- \\
\hline
\end{tabular}

a Inhibition of conidial germination was calculated as follows: [(Number of germinated conidia in the control - Number of germinated conidia in the filtrate) / Number of germinated conidia in the control] x 100. Each value represents the mean of three replicates. Numbers within a column followed by a same letter are not significantly different according to Fisher's protected LSD test $(P<0.05)$. Negative values mean stimulation of conidial germination.

${ }^{\mathrm{b}}$ Not determined.

In confrontation assays on solid media, including when precultures on cellophane membranes were used, $A$. piechaudii, $P$. chlororaphis and $S$. griseus inhibited both mycelial growth and conidial germination of $H$. solani, suggesting that antibiosis is a contributor to the antagonistic effect of these bacteria through the diffusion of antifungal compounds into the medium. Alcaligenes piechaudii, P. chlororaphis and S. griseus had previously been shown to produce antibiotics (Assis et al. 1998; Chin-A-Woeng et al. 1998; Huddleston et al. 1997), though not against $H$. solani.
Arthrobacter oxydans, B. mycoides, K. varians, $R$. erythropolis and $R$. globerulus did not inhibit mycelial growth or conidial germination of $H$. solani, suggesting that antibiosis is not a mechanism by which these bacteria antagonize the pathogen. Although $B$. mycoides (Papou and Gryn'ko 1994), K. varians (Molet et al. 2004; O'Mahony et al. 2001) and Rhodococcus sp. (Hiroyuki et al. 1999) had previously been shown to produce antibiotics, no antibiosis could be revealed with these species against $H$. solani in this study. In accordance with results presented herein, $A$. oxydans had not been previously reported to produce antibiotics.

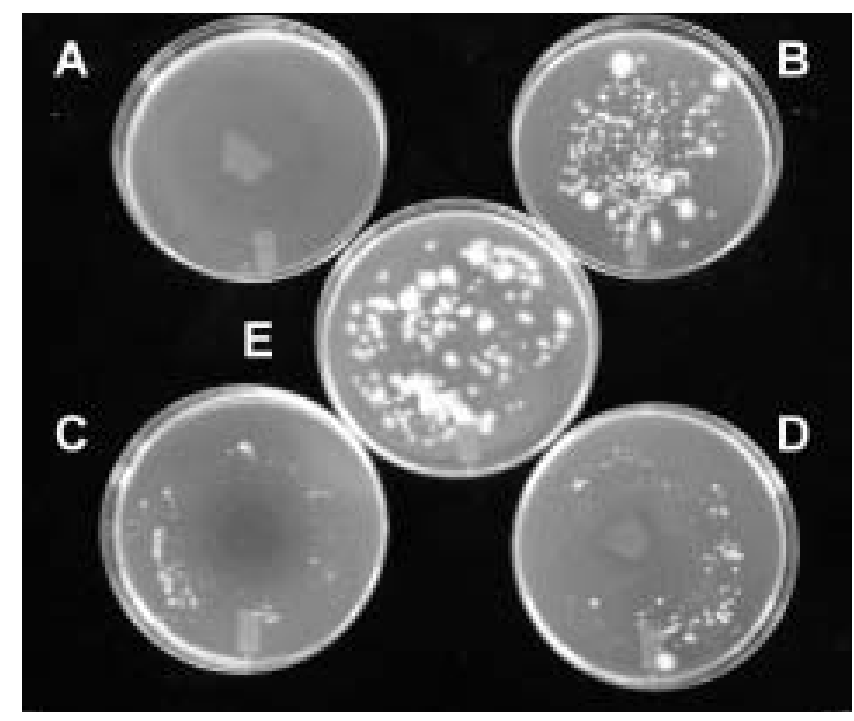

Figure 1. Effect of exudates released by precultured antagonistic bacteria on conidial germination of Helminthosporium solani on solid media. (A) Pseudomonas chlororaphis; (B) Pseudomonas putida (94-19); (C) Streptomyces griseus; (D) Alcaligenes piechaudii; (E) control. 
Aquaspirillum autotrophicum, C. fimi and P. putida (both strains) demonstrated antibiosis against mycelial growth, but not conidial germination of $H$. solani. The production of antifungal compounds by $A$. autotrophicum, C. fimi and P. putida had not been demonstrated previously. Furthermore, the production of siderophores (Sultana et al. 2001) or induced resistance (Ongena et al. 2004) had been determined as the principal modes of action by which $P$. putida strains exerted their antagonistic activity.

Bacillus cereus, $K$. rosea and $P$. fluorescens demonstrated antibiosis against conidial germination of $H$. solani, but did not inhibit its mycelial growth. Bacillus cereus (Handelsman et al. 1990, 1991; Silo-Suh et al. 1994; Smith et al. 1993) and P. fluorescens (Howell and Stipanovic 1979; Jung and Kim 2004; Lynch 1990; Marchand et al. 2000; Thrane et al. 2000) had previously been shown to produce antibiotics, whereas toxic metabolites have not been reported in $K$. rosea. Of particular interest is the filtrate of $P$. fluorescens that displays a strong fungistatic effect on conidial germination. When this same filtrate is washed away from the conidia, germination is stimulated.

When the medium in the confrontation zone from the seven bacteria inhibiting mycelial growth was recovered and extracted, some semi-purified fractions from $A$. piechaudii, C. fimi, $P$. chlororaphis, $P$. putida (94-19) and $S$. griseus exhibited the expected inhibition of mycelial growth in $H$. solani. Fractions from the confrontation zone of $A$. autotrophicum and $P$. putida (E-30) did not demonstrate consistent inhibition of $H$. solani mycelial growth. With pure cultures from the same bacteria, semi-purified fractions also demonstrated antifungal activity against $H$. solani. However, differential antifungal metabolite production was obtained when comparing fractions from dual culture or pure culture systems. For all tested bacteria, with the exception of $P$. putida (94-19), at least one fraction had a different inhibitory effect when comparing dual culture or pure culture systems. Most strikingly, the inhibitory effect of $C$. fimi on $H$. solani switched from fraction F2 in dual culture to F4 in pure culture. This would indicate that different antifungal compounds (or groups of compounds) would be produced depending on the presence or absence of the fungal pathogen. Four likely hypotheses would explain these differences: (i) certain antifungal compounds are only produced in the absence of the pathogen; (ii) certain compounds are only induced in the presence of the pathogen; (iii) the pathogen could detoxify or inhibit certain compounds that are produced in pure culture; and (iv) the same compound could be produced in the absence and presence of the pathogen but in variable quantity, including a low concentration that does not reveal inhibition in $H$. solani. Along these lines, Sonnenbichler et al. (1994) have shown that biosynthesis of a toxic metabolite in Gloeophyllum abiertinum was enhanced up to 400 -fold in the presence of Heterobasidion annosum.

Results also suggest that it is possible that metabolites different from those implicated in mycelial growth inhibition would be involved in the inhibition of conidial germination. Indeed, $A$. autotrophicum, C. fimi and $P$. putida inhibited mycelial growth without affecting conidial germination while $B$. cereus, $K$. rosea and
$P$. fluorescens demonstrated antibiosis against conidial germination of $H$. solani, but did not inhibit its mycelial growth. However, the possibility that $A$. autotrophicum, $C$. fimi and $P$. putida produced metabolites inhibiting conidial germination only in the presence of $H$. solani may not be excluded. Also not to be ruled out is the possibility that metabolic detoxification by $H$. solani occurred when the antifungal compounds from $B$. cereus, $K$. rosea and $P$. fluorescens were gradually produced in dual culture, whereas the high initial concentrations of antifungal metabolites (in the semi-purified fractions) to which conidia were exposed may have overwhelmed the detoxification mechanisms, thus revealing the antifungal effect of the compound(s) for these bacteria. Similar results were obtained with dual cultures of competing Armillaria species, where metabolites from pure cultures possessed inhibitory activity but were detoxified in dual culture (Sonnenbichler et al. 1997).

Séveno et al. (2001) reported that the production of the antibiotic phenazine was six times higher in solid culture when compared with liquid culture in Pseudomonas aureofaciens. In the present study, we also observed that the production of antibiotic compounds may be influenced by the type of medium used (liquid or solid). Indeed, filtrates from pure liquid cultures of $A$. piechaudii and $P$. chlororaphis did not exhibit the antifungal activity on conidial germination they had displayed on solid media. This would indicate that liquid culture of these strains does not induce the production of antifungal compounds, or at least not in amounts that significantly reduce conidial germination.

To our knowledge, this is the first report of antagonists utilizing the production of antifungal metabolites (antibiosis) as a potential component in the biocontrol of $H$. solani. Future work will attempt to isolate and characterize the antifungal metabolites implicated in these interactions, as well as elucidate their specific modes of action. In addition, the results presented herein suggest that care should be taken when identifying the antimicrobial compounds responsible for biocontrol as different compounds may be present depending on the specific methodology employed prior to metabolite extraction. As such, the choice of a specific methodology could eventually expose antibiosis as a mode of action of a particular biocontrol organism whereas other methodologies may not detect antibiosis.

\section{ACKNOWLEDGEMENTS}

The authors thank Caroline Labbé and Denise Auclair for their technical assistance. This work was supported by the National Science and Engineering Research Council (Canada). 


\section{REFERENCES}

Assis, S.M.P., E.B. Silveira, R.L.R. Mariano, and D. Menezes. 1998. Endophytic bacteria - Method for isolation and antagonistic potential against cabbage black rot. Summa Phytopathol. 24 : 216-220.

Avis, T.J., R.R. Boulanger, and R.R. Bélanger. 2000. Synthesis and biological characterization of (z)-9-heptadecenoic and (z)-6-methyl-9-heptadecenoic acids: fatty acids with antibiotic activity produced by Pseudozyma flocculosa. J. Chem. Ecol. 26 : 987-1000.

Bélanger, R.R., N. Dufour, J. Caron, and N. Benhamou. 1995. Chronological events associated with the antagonistic properties of Trichoderma harzianum against Botrytis cinerea: indirect evidence for sequential role of antibiosis and parasitism. Biocontrol Sci. Technol. $5:$ 41-54.

Chin-A-Woeng, T.F.C., G.V. Bloemberg, A.J. van der Bij, K.M.G.M. van der Drift, J. Schripsema, B. Kroon, R.J. Scheffer, C. Keel, P.A.H.M. Bakker, H.V. Tichy, F.J. de Bruijn, J.E. Thomas-Oates, and B.J.J. Lugtenberg. 1998. Biocontrol by phenazine-1-carboxamide-producing Pseudomonas chlororaphis PCL1391 of tomato root rot caused by Fusarium oxysporum f. sp. radicis-lycopersici. Mol. Plant-Microbe Interact. 11 : 1069-1077.

Errampalli, D., J.M. Saunders, and J.D. Holley. 2001. Emergence of silver scurf (Helminthosporium solani) as an economically important disease of potato. Plant Pathol. $50: 141-153$.

Fravel, D.R. 1988. Role of antibiosis in the biocontrol of plant diseases. Annu. Rev. Phytopathol. 26 : 75-91.

Handelsman, J., S. Raffel, E.J. Mester, L. Wunderlich, and C.R. Gau. 1990. Biological control of damping-off of alfalfa seedlings with Bacillus cereus UW85. Appl. Environ. Microbiol. 56 : 713-718.

Handelsman, J., W.C. Nesmith, and S.J. Raffel. 1991 Microassay for biological and chemical control of infection of tobacco by Phytophthora parasitica var. nicotianae. Curr. Microbiol. 22 : 317-319.

Hiroyuki, C., A. Hitosi, K. Rei, T. Tadashi, S. Kasuya, D. Kazuyuki, and Y. Takeo. 1999. Rhodopeptins (MerN1033), novel cyclic tetrapeptides with antifungal activity from Rhodococcus sp.: I. Taxonomy, fermentation, isolation, physico-chemical properties and biological activities. J. Antibiot. 52 : 695-699.

Howell, C.R. and R.D. Stipanovic. 1979. Control of Rhizoctonia solani on cotton seedlings with Pseudomonas fluorescens and with an antibiotic produced by the bacterium. Phytopathology $69: 480-482$.

Huddleston, A.S., N. Cresswell, M.C.P. Neves, J.E. Beringer, S. Baumberg, D.I. Thomas, and E.M.H. Wellington. 1997. Molecular detection of streptomycin-producing Streptomycetes in Brazilian soils. Appl. Environ. Microbiol. 63 : 1288-1297.

Jung, H.K., and S.D. Kim. 2004. Selection and antagonistic mechanism of Pseudomonas fluorescens 4059 against phythophthora blight disease. Korean J. Microbiol. Biotechnol. 32 : 312-316.

Lynch, J.M. 1990. Microbial metabolites. Pages 177-206 in J.M. Lynch (ed.), The Rhizosphere. John Wiley \& Sons, New York.

Marchand, P.A., D.M. Weller, and R.F. Bonsall. 2000. Convenient synthesis of 2,4-diacetylphloroglucinol, a natural antibiotic involved in the control of take-all disease of wheat. J. Agric. Food Chem. 48 : 1882-1887.

Martinez, C., M. Michaud, R.R. Bélanger, and R.J. Tweddell. 2002. Identification of soils suppressive against Helminthosporium solani, the causal agent of potato silver scurf. Soil Biol. Biochem. 34 : 1861-1868.
Mérida, C.L., and R. Loria. 1994. Comparison of thiabendazole-sensitive and-resistant Helminthosporium solani isolates from New York. Plant Dis. 78 : 187-192.

Michaud, M., C. Martinez, A.-M. Simao-Beaunoir, R.R. Bélanger, and R.J. Tweddell. 2002. Selection of antago nist microorganisms against Helminthosporium solani, causal agent of potato silver scurf. Plant Dis. 86 : 717-720.

Molet, B., J. Peel, D. Pridmore, N. Rekhif, and B. Suri. 2004 Bactericide compositions prepared and obtained from Micrococcus varians. Off. Gaz. U.S. Pat. Trademark Off. Pat. p. 1279

O'Mahony, T., N. Rekhit, C. Cavadini, and G.F. Fitzgerald. 2001. The application of a fermented food ingredient containing 'variacin' a novel antimicrobial produced by Kocuria varians, to control the growth of Bacillus cereus in chilled dairy products. J. Appl. Microbiol. 90 : 106-114.

Ongena, M., F. Duby, F. Rossignol, M.L. Fauconnier, J. Dommes, and P. Thonart. 2004. Stimulation of the lipoxygenase pathway is associated with systemic resistance induced in bean by a nonpathogenic Pseudomonas strain. Mol. Plant-Microbe Interact. 17 : 1009-1018.

Papou, F.A., and N.M. Gryn'ko. 1994. Ecologically safe methods of protection of seed white head cabbage and winter cauliflower. Vesti Akademii Agrarnykh Navuk Belarussi $3: 54-59$.

Platt, H.W. 1997. Resistance to thiabendazole in Fusarium species and Helminthosporium solani in potato tubers treated commercially in eastern Canada. Phytoprotection $78: 1-10$.

Secor, G.A., and N. Gudmestad. 1999. Managing fungal diseases of potato. Can. J. Plant Pathol. 21 : 213-221.

Séveno, N.A., J.A.W. Morgan, and E.M.H. Wellington. 2001. Growth of Pseudomonas aureofaciens PGS12 and the dynamics of $\mathrm{HHL}$ and phenazines production in liquid culture, on nutrient agar, and on plant roots. Microb. Ecol. 41 : 314-324.

Silo-Suh, L.A., B.J. Lethbridge, S.J. Raffel, H. He, J. Clardy, and J. Handelsman. 1994. Biological activities of two fungistatic antibiotics produced by Bacillus cereus UW85. Appl. Environ. Microbiol. 60 : 2023-2030.

Smith, K.P., M.J. Havey, and J. Handelsman. 1993. Suppression of cottony leak of cucumber with Bacillus cereus strain UW85. Plant Dis. 77 : 139-142.

Sonnenbichler, J., J. Dietrich, and H. Peipp. 1994. Secondary fungal metabolites and their biological activities. V. Investigations concerning the induction of the biosynthesis of toxic secondary metabolites in basidiomycetes. Biol. Chem. Hoppe-Seyler 375 : 71-79.

Sonnenbichler, J., J.J. Guillaumin, H. Peipp, and D. Schwarz. 1997. Secondary metabolites from dual cultures of genetically different Armillaria isolates. Eur. J. For. Pathol. 27 : 241-249.

Sultana, R., B.S. Siddiqui, K. Taraz, H. Budzikiewicz, and J.M. Meyer. 2001. An isopyoverdin from Pseudomonas putida CFML 90-33. Tetrahedron 57 : 1019-1023.

Thrane, C., T.H. Nielsen, M.N. Nielsen, J. Sorensen, and S. Olsson. 2000. Viscosinamide-producing Pseudomonas fluorescens DR54 exerts a biocontrol effect on Pythium ultimum in sugar beet rhizosphere. FEMS Microbiol. Ecol. 33 : 139-146.

Whipps, J.M. 1987. Effect of media on growth and interactions between a range of soil-borne glasshouse pathogens and antagonistic fungi. New Phytol. 107 : 127142. 